\title{
Research Paper \\ Comparison of the Effectiveness of Individual and Group Play Therapy on Coping Behaviors in Primary School Students with Attention Deficit Hyperactivity Disorder
}

Elahe Nayebi ${ }^{1}$, Reza Pasha*2, Saeed Bakhtiyarpour ${ }^{3}$, Zahra Eftekhar Saadi ${ }^{3}$

1. Ph.D. Student of Psychology of Exceptional Children, Ahvaz Branch, Islamic Azad University, Ahvaz, Iran 2. Associta Professor, Department of Psychology, Ahvaz Branch, Islamic Azad University, Ahvaz, Iran 3. Assistant Professor, Department of Psychology, Ahvaz Branch, Islamic Azad University, Ahvaz, Iran

Citation: Nayebi E, Pasha R, Bakhtiyarpour S, Eftekhar Saadi Z. Comparison of the effectiveness of individual and group play therapy on coping behaviors in primary school students with attention deficit hyperactivity disorder. Quarterly Journal of Child Mental Health. 2020; 7(2): 120-131.

\section{http://dx.doi.org/10.29252/jcmh.7.2.11}

\section{A R T I C L E I N F O}

\section{Keywords:}

Individual play therapy, group play therapy, coping behaviors, ADHD

Received: 28 May 2019 Accepted: 2 Jun 2020 Available: 21 Sep 2020

\section{A B S T R A C T}

Background and Purpose: Play therapy is an innovative psychotherapy technique in child therapy. This therapy can fulfill the needs of children in different ages and it can significantly affect their behavior change, adaptability, and social skills. Present study aimed to compare the effectiveness of individual and group play therapy on the coping behaviors of students with Attention Deficit Hyperactivity Disorder (ADHD).

Method: This study was an experimental research with pretest- posttest control group design. The study population included all the male and female students with ADHD in Tehran in the academic year 2018-2019. A sample of 60 students was selected by purposive sampling and then randomly assigned to either the experimental or control group (20 per group). The experimental group underwent ten 45-min sessions of individual play therapy and ten 60-min sessions of group play therapy, but the control group received no intervention. Oppositional Behaviors Questionnaire (Falahi et al., 2017) and Conner's ADHD Rating Scale (1999) were used to gather the data. Data were analyzed by ANCOVA.

Results: Findings showed that both individual and group play therapy were effective in increasing the component of problem coping $(\mathrm{F}=217.93)$, decreasing the component of solution aversion $(\mathrm{F}=1153.09)$ and destructive coping $(\mathrm{F}=317.57)$ in primary students with ADHD $(\mathrm{p}<0.01)$. Also, based on the findings of follow-up test, group play therapy was more effective than individual play therapy in terms of increasing the component of problem coping ( $\mathrm{MD}=-3.61)$ and decreasing the components of solution aversion $(\mathrm{MD}=4.65)$ and destructive coping $(\mathrm{MD}=3.66)$ in primary school students with ADHD ( $\mathrm{p}<0.01)$.

Conclusion: Individual and group play therapy are effective in increasing the coping behaviors of primary school students with ADHD but based on the results, group play therapy can be more effective in improving the mental and behavioral situation of children.

\footnotetext{
* Corresponding author: Reza Pasha, Associta Professor, Department of Psychology, Ahvaz Branch, Islamic Azad University, Ahvaz, Iran. E-mail addresses: G.rpasha@yahoo.com
} 


\title{
مقايسه اثربخشى بازىدرمانى انفرادى و كروهى بر رفتارهاى مقابلهاى در دانش آموزان دبستانى

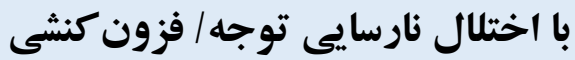

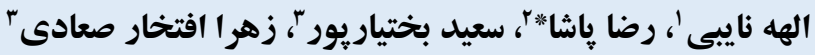

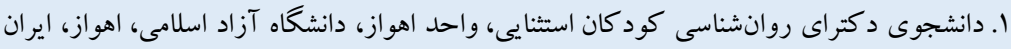

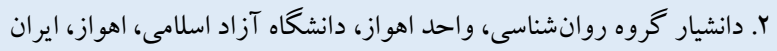

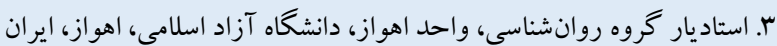

جكي"

زمينه و هدف: بازىدرمانى، روشى خلاقانه در رواندرمانى كودك است و اين درمان متناسب با سن، نيازهاى كود كان در زمينههاى سنى مختلف را بر آورده كرده و بر تغيير رفتار، سازشيافتكى، و مهارتهاى اجتماعى آنها، اثر مهمى دارد. يخوهش حاضر با هدف مقايسه

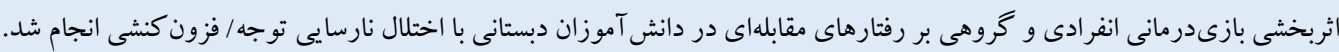
روش: طرح اين يُوهش، تجربى از نوع ييش آزمون-ِّ آزمون با گروه كنترل بود. جامعه آمارى اين مطالعه شامل تمامى دانش آموزان

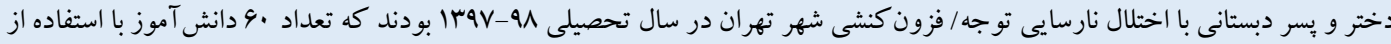

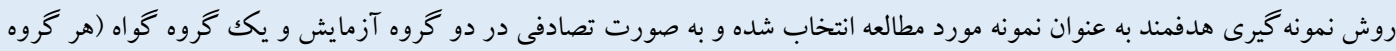

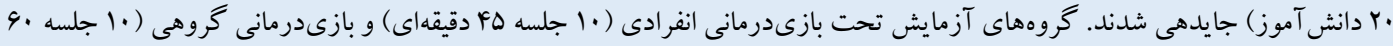

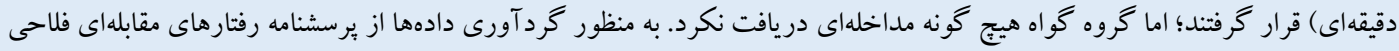

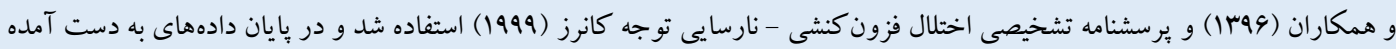
با استفاده از آزمون آمارى تحليل كوواريانس، تحليل شدند.

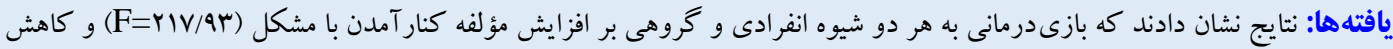

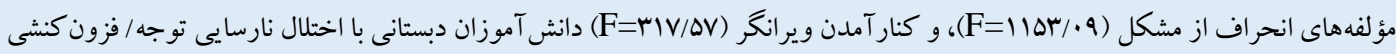

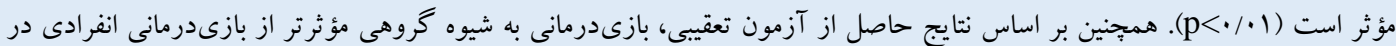
افزايش مؤلفه كنار آمدن با مشكل (

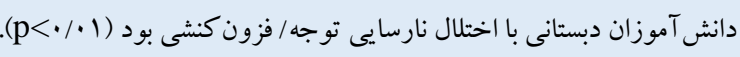

نتيجه كيرى: بازىدرمانى انفرادى و گروهى بر افزايش رفتارهاى مقابلهاى دانش آموزان دبستانى با اختلال نارسايى توجه/ فزون كنشى

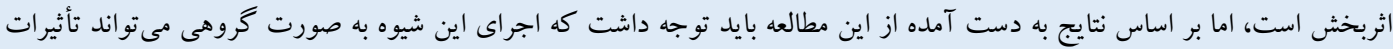

$$
\text { بيشترى بر بهبود وضعيت روانى و رفتارى كود كان داشته باشد. }
$$

مشخصات مقاله

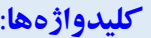

بازى درمانى انفرادى،

بازى درمانى گروهى،

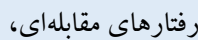

اختلال نارسايى توجه / فزون كنشى

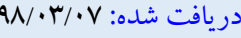

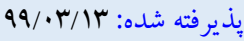

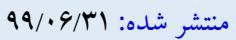

* نويسنده مسئول: رضا ياشا، دانشيار كروه روانشناسى، واحد اهواز، دانشخاه آزاد اسلامى، اهواز، ايران.

رايانه: G.rpasha@yahoo.com

تلفن: 
كو دان مبتلا به آن، ملاككهاى كامل اختلال رفتار هنجارى را ندارند، اما

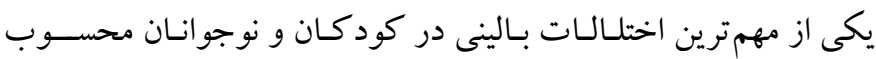

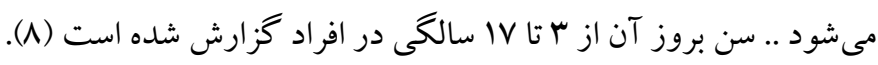

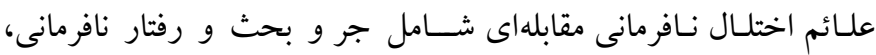
يرخاشـخرى، كينهورزى، و خلق بىثبات اسـت كه بايد حدود 9 ماه به

طول بيانجامد (9-9 (I).

روانشـناسـان و متخصصــان براى كاهش و يا رفع علائم و مشكلات

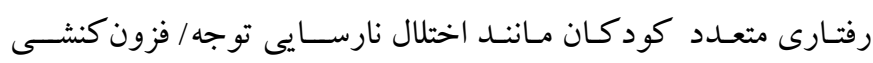

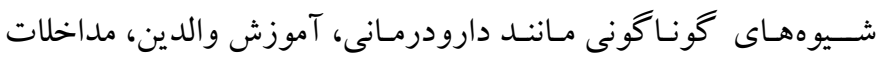

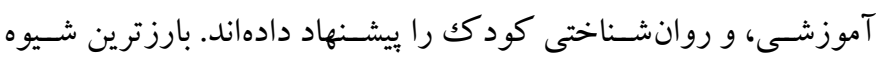

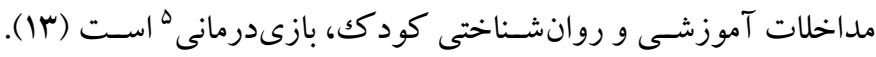

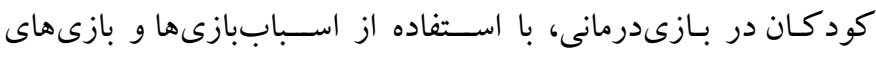

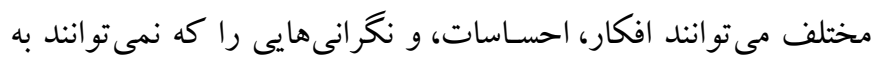
خوبى نشـان دهند، در جارجوب بازى هاى مختلف ابراز كنند. كودك

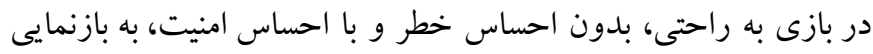
نمـادين و عينى اسـبـاببـازىهـا در دنياى درونى خود مى يردازد و

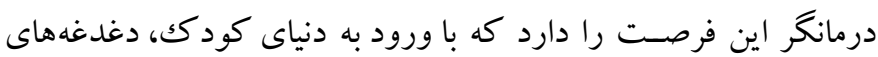

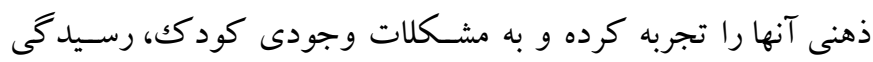

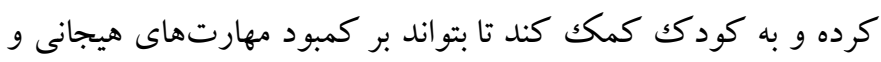
اجتماعى خود غلبه كند (f) (1). به طور كلى، بازىدرمانى، فعاليتى خلاقانه

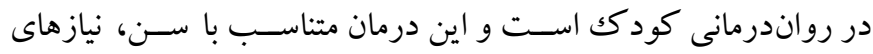
كود كان در زمينههاى سـنى مختلف را بر آورده كرده و بر تغيير رفتار، سازش يافتكى، و مهارتهاى اجتماعى كود كان، تأثير مهمى دارد (هان (1).

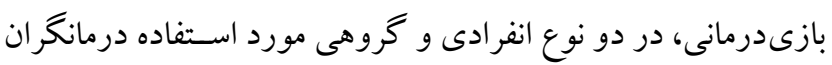

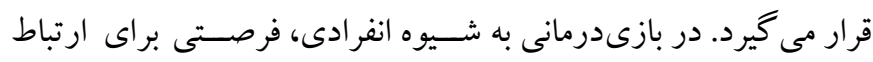

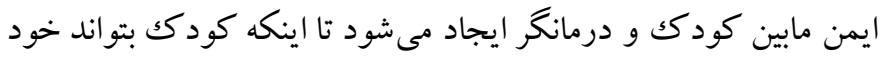

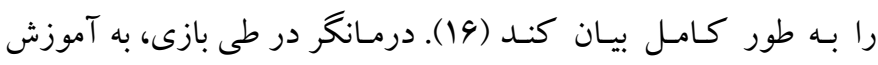

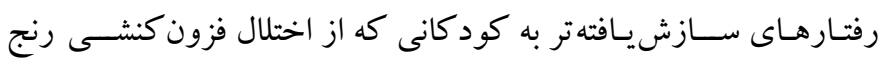
مى برند و تمر كز و مهارت هاى اجتماعى يا عاطفى ضعيفى دارند، به طور

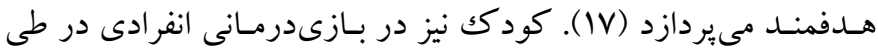

4. Conduct disorder (CD)

5. Play therapy
مقلهم

طبق گزارش سـازمان جهانى سـلامت، حدود · r درصـد از كودكان و نوجو انان به انواع اختلالهاى روانى مبتلا هستـند و اين آمار هر سـال در

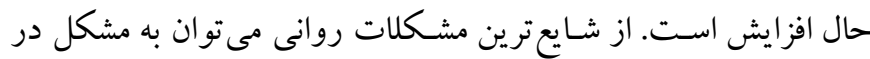

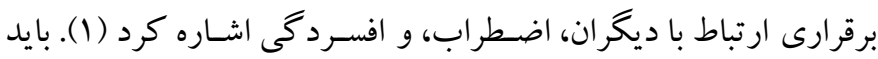
توجـه داشـت كه درصــد واقعى كود كان و نوجوانانى كه با اختلالات

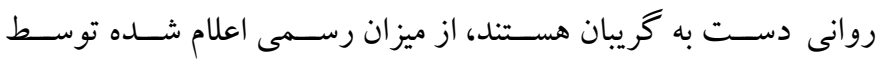

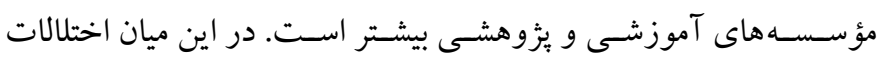
ياد گيرى، خلقى، و نارسـايى توجه / فزون كنشسى از شـايع ترين مشـكلات

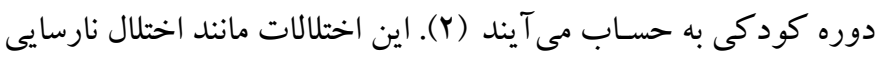

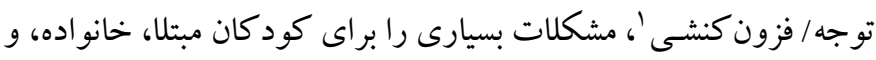
معلمان آنها ايجاد مى كنند.

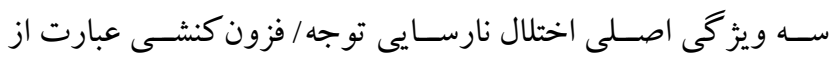

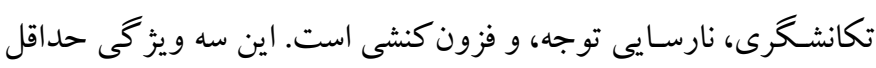

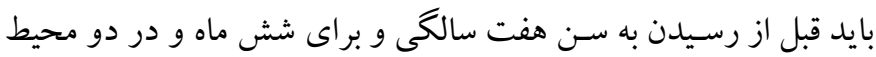

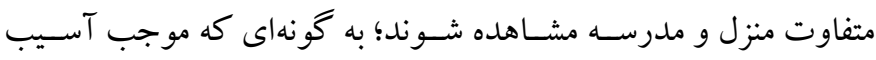

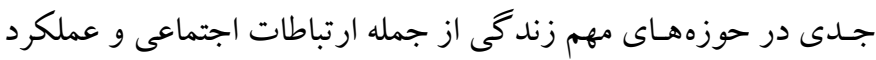

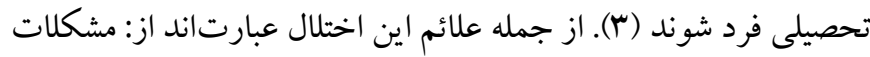

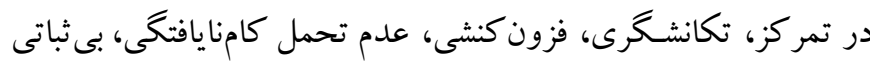

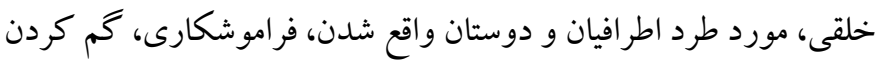
وسايل، و كجخلقى (F). بر اساس مطالعه انجام شده، شيوع اين اختلال را

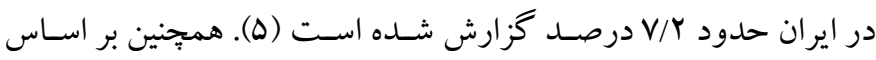

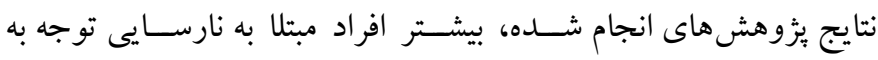

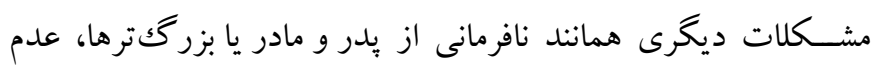

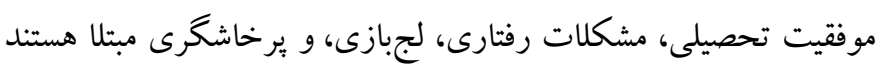

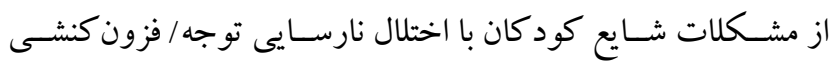

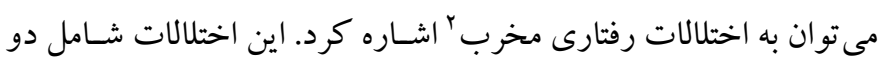

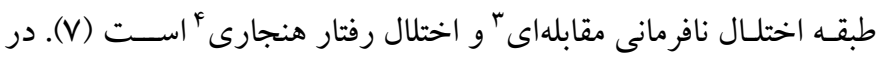

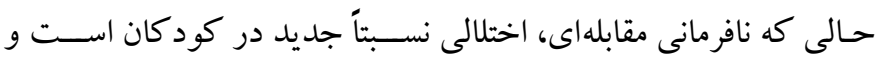

1. Attentiond deficit/ hyperactivity disorder (ADHD)

2. Disruptive behavioral disorders

3. Oppotional defieant disorder (ODD) 
شــكلهـا و روش هـاى گوناكونى براى اجراى بازىدرمانى به كار رفته

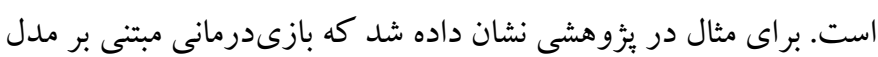

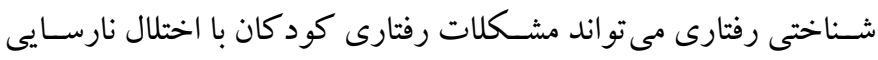
توجه / فزون كنشـى را كاهش داده و مهارتهاى اجتماعى آنها را بهبود

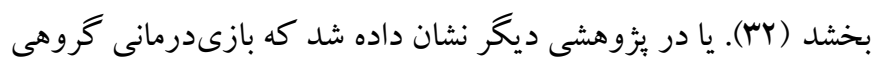
مبتنى بر كنشهاى اجرايى بر بهبود بازدارى پاســـخ، برنامهريزى، و و

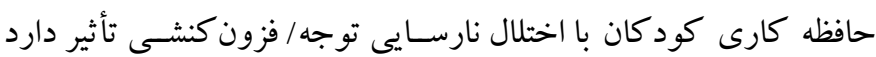
(سب). بدين تر تيب همان طور كه مشاهده مى كنيم مطالعات اندكى درباره

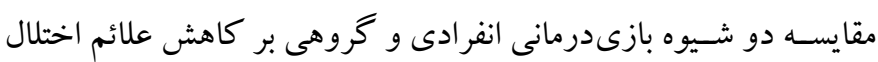

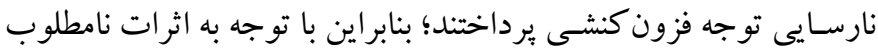

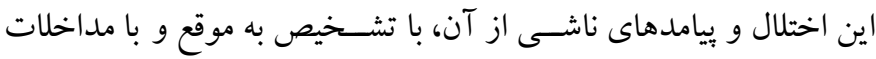

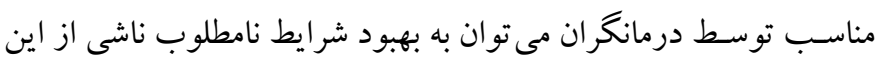
اختلال و كاهش رفتارهاى مقابلهاى در اين كود كان كمكك مؤثرى ارائه

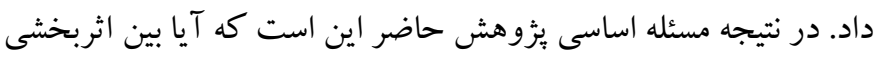

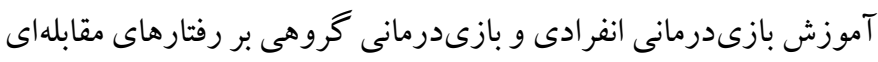

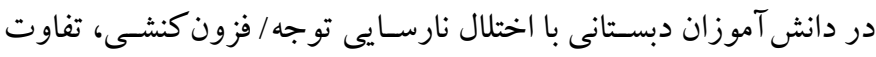

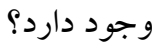

روش الف) طرح يزوهش و شر كت كنند كان: ئزوهش حاضر از نظر هدف،

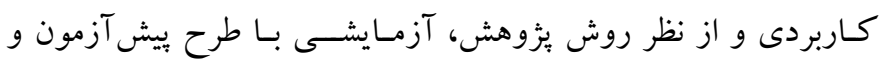

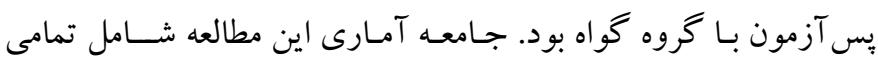

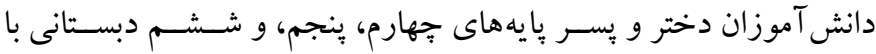

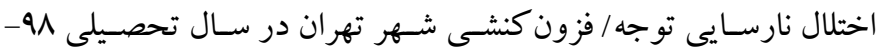
1T9V بودند. براى انتخاب نمونه ابتدا از بين مدارس دبستانى شهر تهران،

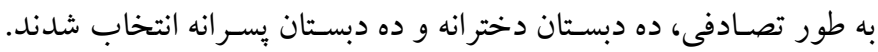

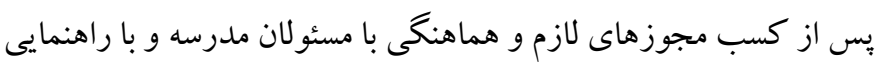

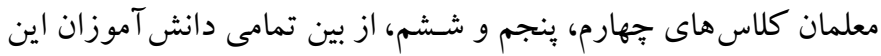

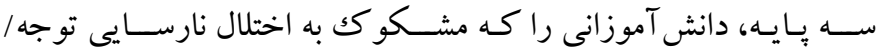

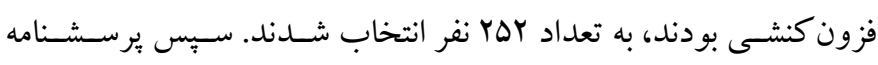
تشـخيص اختلال نارسـيى توجه / فزون كنشى كانرز (توضيح اين آزمون

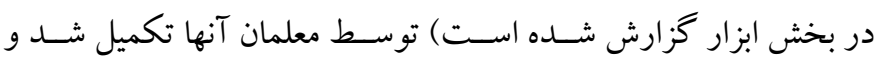

تعـاملات بين فردى بـا درمانگر، به تجربه كاهش اثرات رنج آور، يذيرش

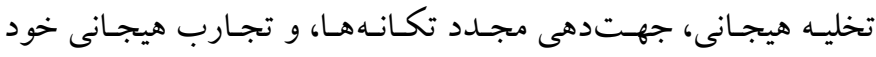

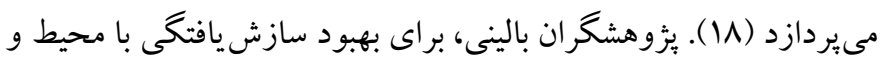

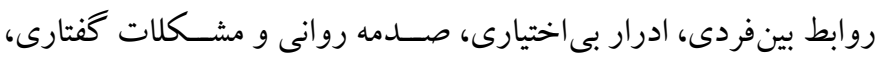

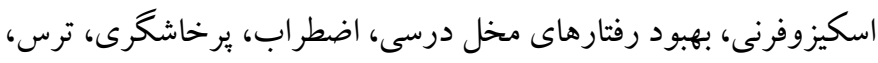

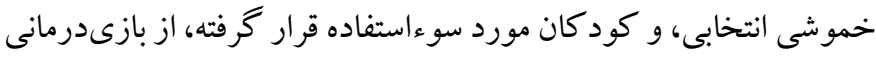

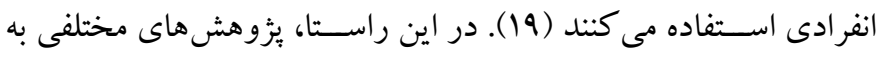

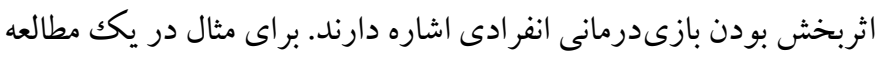

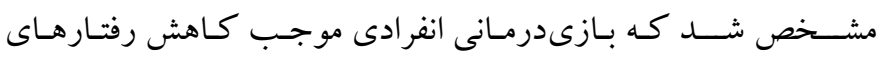

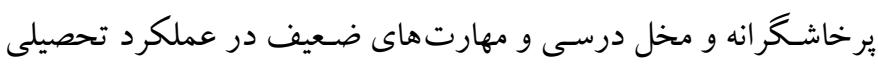

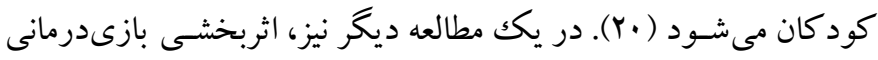

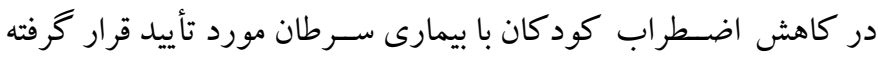

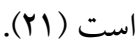

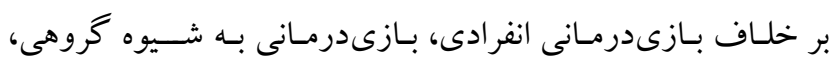

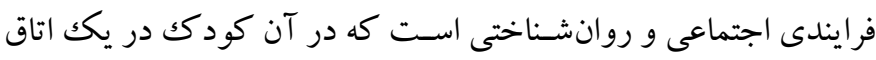

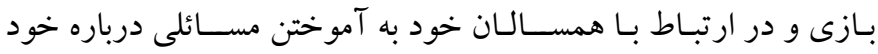

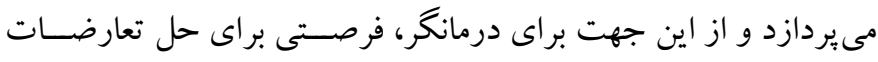

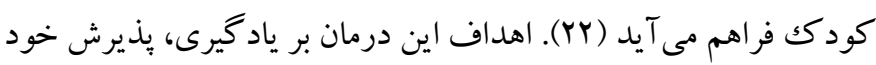

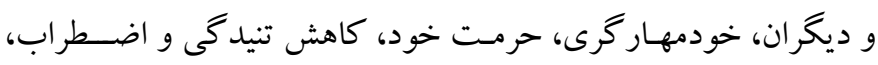

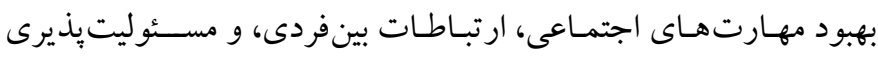

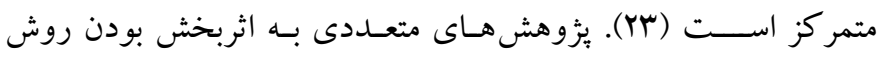

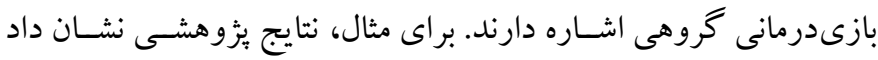

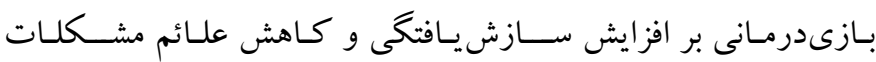

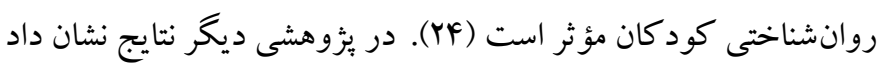

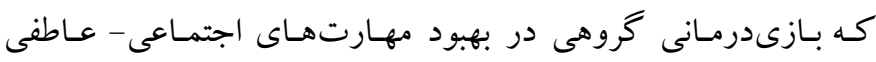

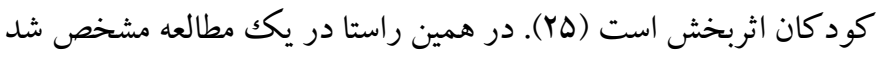

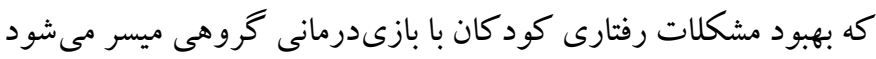

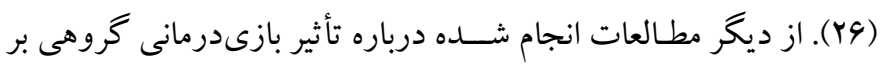

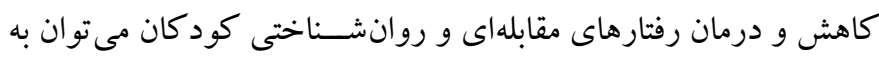
بزُوهش هاى مرشـد، باباميرى، زمستانى و علييور (YV)؛ علوى، رضوى و

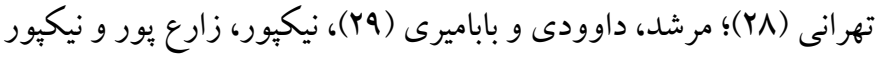

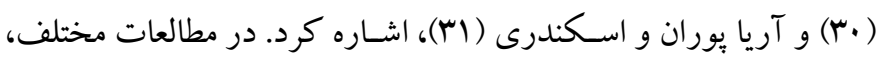


و با انجام تحليل عاملى، سه عامل شامل انحراف از مشكل، كنار آمدن با

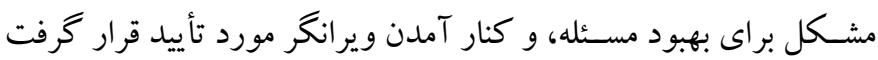

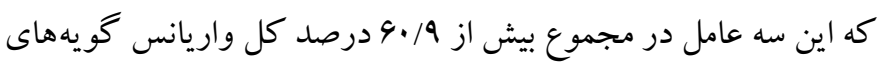

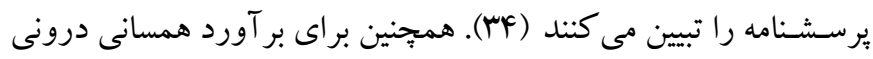
نيز از ضريب آلفاى كرونباخ استفاده شده كه اين شاخص براى نمره كل 19/، • و مؤلفه هاى انحراف از مشكل، كنار آمدن با مشكل، و كنار آمدن

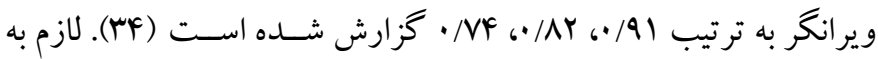

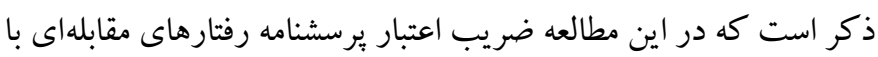

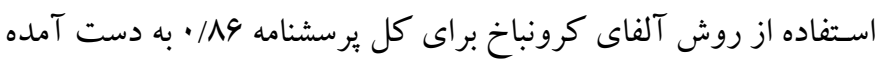

r. برسشـنامه تشخيصى اختلال فزونكنشى - نارسا يیى توجه كانرزّ". در

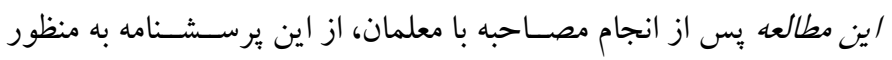
تشـخيص قطعى اختلال نارسـايى توجه- فزون كنشـى در دانش آموزان استفاده شد. اين مقياس توسط كانرز و همكاران (هاr) در سال 1999 تهيه شـــ و داراى צY گويه صــفر تا سـه امتيازى و وينج خردهمقياس اسـت.

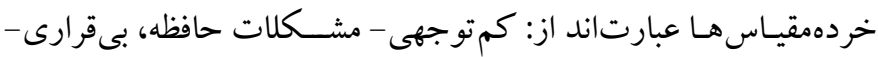
فزون كنشى، بى ثباتى هيجانى - تكانهاى بودن، مشكلات با تصور كلى از خود، شاخص فزون كنشى- نارسايى توجه. هر يكك از جهارخردهمقياس

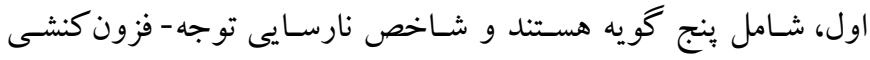

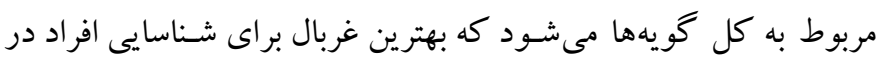
معرض خطر اختلال است. نمرات خام هر خردهمقياس با استفاده از جدول

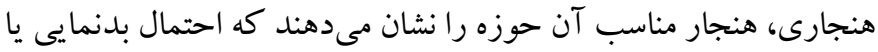
اغراق در علـائم را نيز مطرح مى كنـــ شــاخصهــاى روانســنجى اين

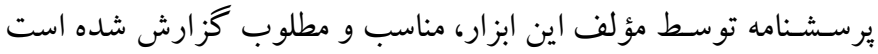

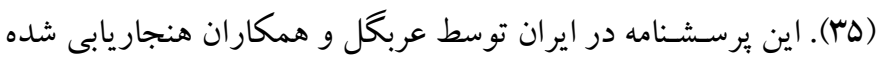

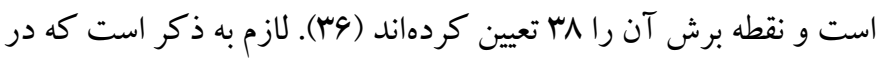
اين مطالعه ضـريب اعتبار برسشــامه تشـخيصى اختلال نارسـيى توجه-

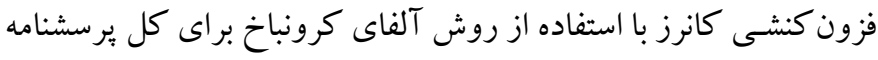
•^/ • به دست آمده است كه مطلوب و رضايتبخش است.
يرسـشــنامه رفتارهاى مقابلهاى كود كان (معرفى شــــه در بخش ابزار)،

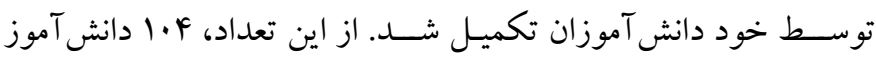
داراى اختلال نارسـايى توجه/ فزون كنشى تشخيص داده شدند و همجيجنين

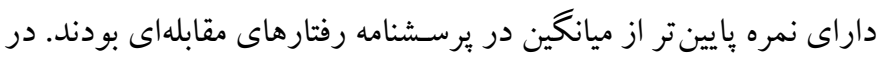

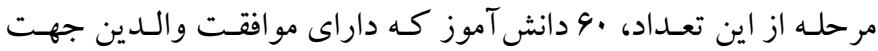
شـركت در يزوهش بودند و بر حسـب شـــ ايط ورود و خروج به عنوان

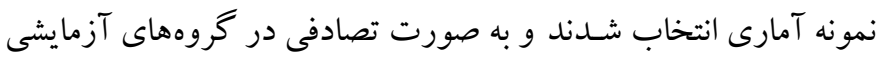

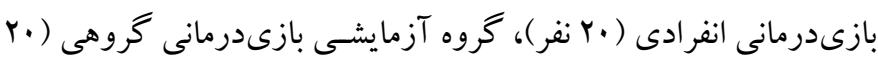

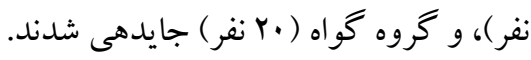

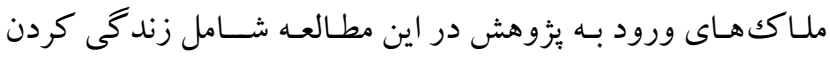

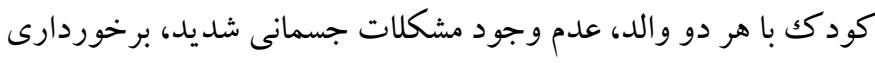

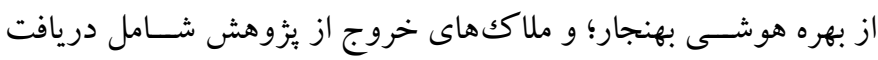

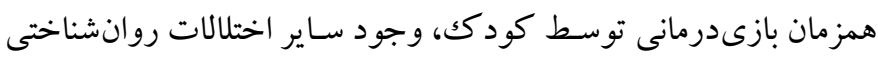
همبود در كود كك مـانــد اختلـال نـافرمانى مقابلهاى، و غيبت بيش از دو جلسه در درمان بود.

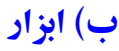

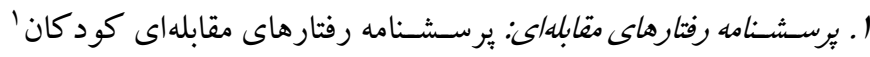

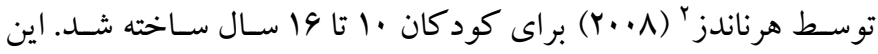

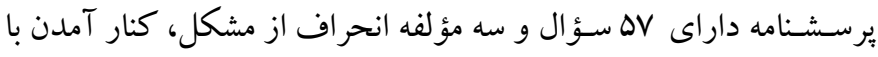

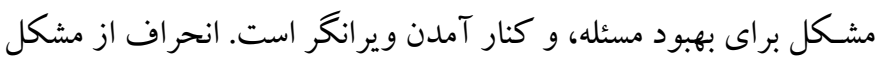

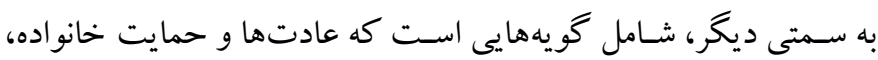
تفكر مثبت، و حواس يرتى را مى ســجد؛ كنار آمدن با مشـكل، به منظور بهبود مشكل يا سعى در يافتن راهحل مسئله و بيان هيجان از طريق تمركز

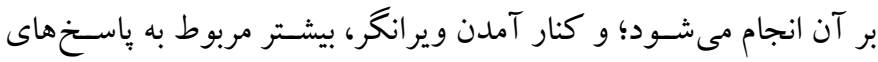

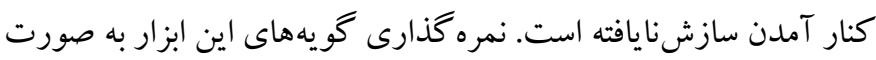

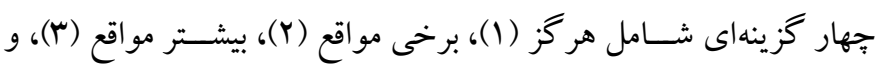

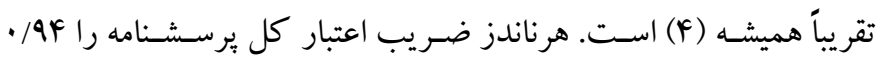
كزارش كرده اسـت و روايى آن را با تحليل عاملى مورد تأييد قرار داده

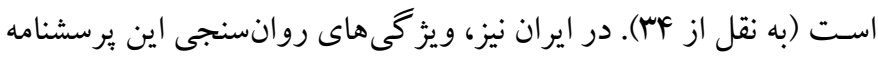

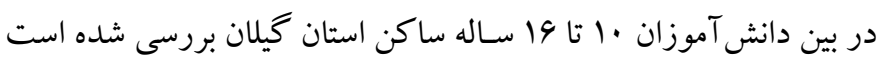

1. Children's coping behavior questionnaire (CCBQ) 2. Hernandez 
نخخست اين مقاله در مدارس دانش آموزان اجرا شـــه اسـت. خلاصـهـ

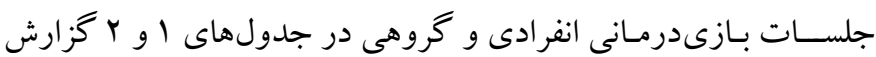

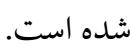

ج) برنـامــه مــداخله: برنامه مداخله در اين مطالعه شــامل · جلســه

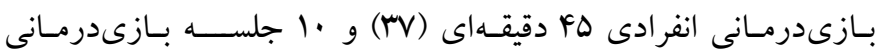

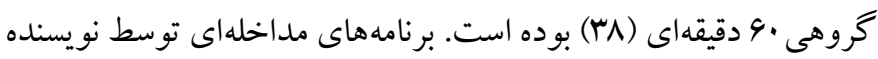

\section{جدول 1: خلاصه جلسات بازىدرمانى انفرادى}

\begin{tabular}{|c|c|c|}
\hline 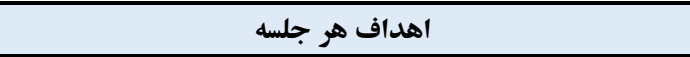 & 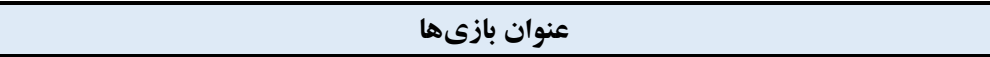 & جلسه \\
\hline وارسى كردن و توجه به اشيا & هوش جين، كارتهاى توجه (كارت شلوغ)، تغيير جا به جا كردن اشياء روى ميز و حدس زدن اين تغيير & 1 \\
\hline توجه به جزء در ارتباط با كل، توجه به جزئيات، افزايش توجه ديدارى و & بازل، كارتهاى تكميل ديدارى و جورجين & $r$ \\
\hline افزايش تمركز، توجه و دقت در نظر گرفتن توالى و ترتيب & نخ كردن مهرهها، قصه كويى، كارت تفاوتها و شباهتها & $r$ \\
\hline توجه و تمركز به الكوبردارى و كار با اشياء & موزايكك رنخى، مخنت، جورجين يا مينياتور & r \\
\hline توجه به كفتار و رفتار بزركسالان و اجراى دستور العملها & بازى هِ، نان بياركباب ببر، يه مرغ دارم روزى جند تا تخم ميذاره، سنك كاغذ قيجى، كلاغ بر & $\Delta$ \\
\hline رعايت قوانين و رعايت نوبت، خودتنظيمى و خودمهار خرى، و توانايى & جينكا، ريسمان گريز دستمال يشت سرى، بانتوميم & 4 \\
\hline هماهنك كردن حر كات خود با ديخر ان و رعايت قوانين و نوبت ديخران & راننده و مسافر و نقاشى با انگشت روى مقوا به صورت گروهى & $\checkmark$ \\
\hline 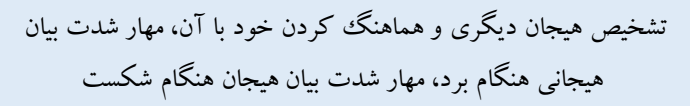 & گرقى يخى، حدس بزن اين حيه، شكلك در آوردن و سوزندان طرف مقابل & $\wedge$ \\
\hline ابراز هيجانات به طور كلامى و غير كلامى & بازى كلمات، احساسات، بازى زندگى خود را رنكى بزن، ميله هاى رنخى & 9 \\
\hline كاهش حواسيرتى و مهار رفتار و هيجان، مرورى بر افزايش توجه & كارتهاى توجه، دومينو عددى، بازل و جينكا & 1. \\
\hline
\end{tabular}

جدول r: خلاصه جلسات بازىدرمانى كروهى

\begin{tabular}{|c|c|c|}
\hline اهداف هر جلسه & عنوان بازىها & جلسه \\
\hline ايجاد تمر كز و دقت روى بازىها و برقرارى شروع ارتباط & بازى با عروسك و تامى تامى اسكيت & 1 \\
\hline توجه به كفتار و رفتار بزر كَالان و افزايش توجه شنيدارى و تمركز & بازى استب رقص با موسيقى، تعريف يك قصه و اجراى آن به روش ايفاى نقش، بشين ياشو & r \\
\hline توجه به كفتار هم گروهىهاى خود و افزايش تمر كز حواس & قطار بازى با موسيقى، قصه كويى توسط تكك تكك بجهها و به اجرا در آوردن يكك قصه، بجههاى گمشده & r \\
\hline توجه و دقت روى مهار رفتار و توانايى نشستن به هنخام لزوم & تولد بازى، تامى تامى اسكلت، ييكك نيك رفتن، صندلى بازى، بشين ياشو & r \\
\hline توانيى رعايت قانون و رعايت نوبت و تعامل با ديخران & مسابقه كترل كردن بادكنك روى مقوا، جرخاندن باد كنك به نوبت در دستان هم ديكر همراه موسيقى، مسابقه & $\Delta$ \\
\hline هماهنك كردن حر كات خود با ديكران و افزايش تمركز حواس و و عكس العمل دقت & ريسمان كَريز، جينكا، بانتوميم، دستمال بشت سرى & 9 \\
\hline ابراز هيجانات به صورت غير كلامى و حس تعامل و رقابت بين بجه & نقاشى با انغشت روى مقوا به صورت گَروهى و راننده و مسافر & $v$ \\
\hline تشخيص هيجان ديخر ان و هماهنك كردن خود با ديخران & شكلك در آوردن و سوزندان طرف مقابل، گر گى يخى و حدس بزن اين جيه & $\wedge$ \\
\hline ابزار هيجانات به صورت كلامى و حس تعاون و همكارى، مهار & واليبال بازى با بادكنك، صندلى بازى، فروشنده و مشترى و يز شكك و بيمار & 9 \\
\hline بازنخرى رفتارها در كودكان و مرور جلسات گذشته & بشين و ياشو، واليبال بازى، دستمال يشت سرى تامى تامى اسكلت & 1. \\
\hline
\end{tabular}

ارائه شــده، انتخاب شـــهاند و ييش آزمون از همه آنها توســ ابزارهاى

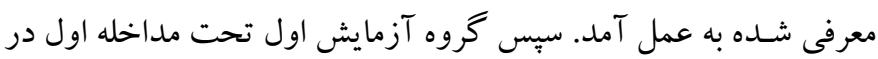

د) روش اجرا: بعـــ از كســبـ مجوزهــاى لـازم علمى و اخلـاقى از

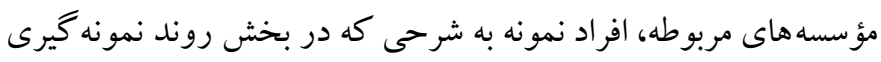


والـدين آنها، اخذ شــــ. در بايان دادههاى جمع آورى شـــده در مراحل ييش آزمون و يس آزمون با آزمون آمارى تحليل كوواريانس مورد تجزيه و تحليل قرار كرفتند.

\section{يافتهها}

ميانگين و انحراف اســاندارد نمرات بيش آزمون- بـ بـ آزمون متغيرهاى

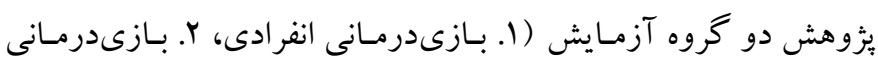

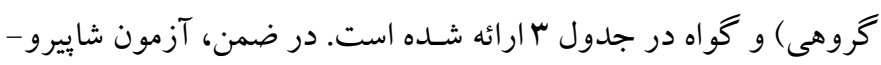

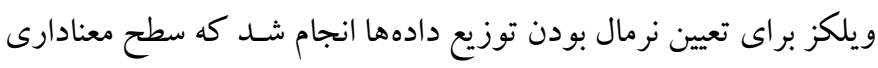

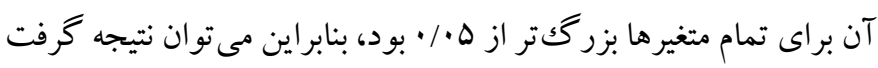

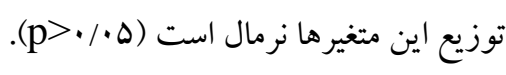

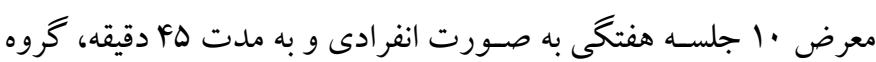

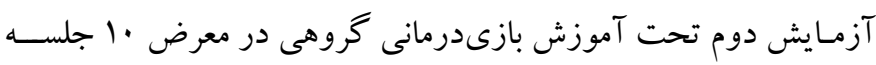

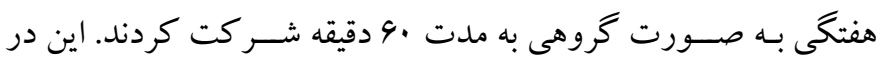

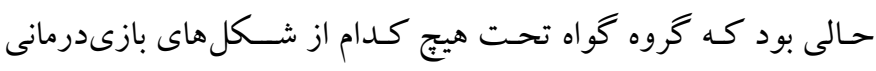

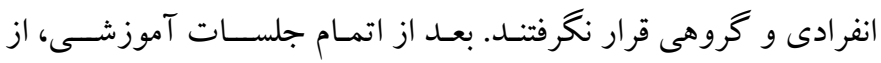

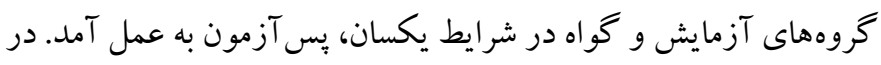

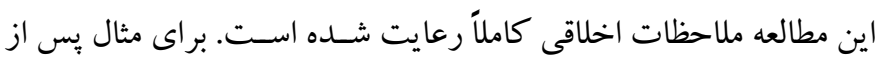

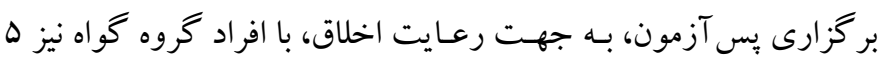

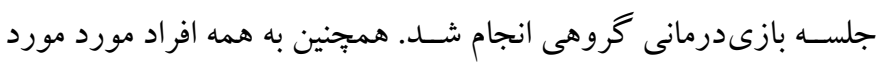

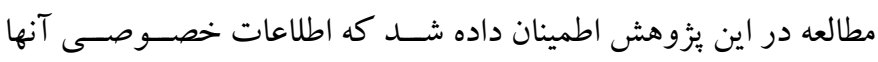
محرمانه باقى خواهد ماند و رضـايت كامل هم از دانش آموزان و هم از از

جدول r: شاخصهاى توصيفى نمرات ييشآزمون- بس آزمون در دو كروه آزمايش و كواه (تعداد كل: عاع)

\begin{tabular}{|c|c|c|c|c|c|c|c|}
\hline \multicolumn{2}{|c|}{ كواه } & \multicolumn{2}{|c|}{ بازىدرمانى كروهى } & \multicolumn{2}{|c|}{ بازىدرمانى انفرادى } & \multirow{2}{*}{ وضعيت } & \multirow{2}{*}{ متغير وابسته } \\
\hline انحر اف معيار & ميانكين & انحر اف معيار & ميانكين & انحر اف معيار & ميانغين & & \\
\hline $1 / r \Delta$ & r & $1 / 19$ & TY/AV & $1 / r r$ & rY/ar & ي يش آزمون & \multirow{2}{*}{ انحر اف از مشكل } \\
\hline $1 / r$ & $M T / A V$ & $1 / 99$ & $r \mathrm{rr} / \mathrm{A}$. & $1 / 0$ & YN/F. & يس آزمون & \\
\hline $1 / 10$ & rY/A. & $1 / 11$ & $r \Delta / 9 \mathrm{~V}$ & $1 / \pi$ & rr/ar & ييش آزمون & \multirow{2}{*}{ كنار آمدن با مشكل } \\
\hline $1 / 1$. & rY/qR & $1 / 01$ & $r$. & $1 / Y F$ & $r q / F V$ & يس آزمون & \\
\hline $1 / 94$ & $M T / 9 V$ & $1 / 91$ & $M r / q$. & $1 / 49$ & $r \mathrm{r} / 9 \mathrm{r}$ & ي يش آزمون & \multirow{2}{*}{ كنار آمدن وير انغر } \\
\hline $1 / N r$ & $M T / \Delta r$ & $\cdot / \mathrm{VV}$ & $r \Delta / A$. & $1 / r$. & $r q / F$. & يس آزمون & \\
\hline
\end{tabular}

و گواه نيز نشان داد كه ماتريس كوواريانس متغيرهاى وابسته در گروه ها برابر اسـت ( BOX M= 3.16, F= 0/52 P>0.05). نتايج آزمون خى دو بـارتلـت براى بررسـى كرويت يا معنادارى رابطه بين مؤلفههاى

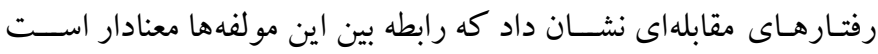

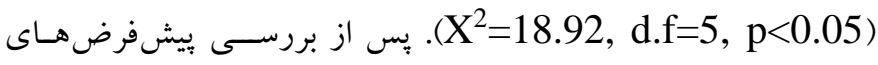

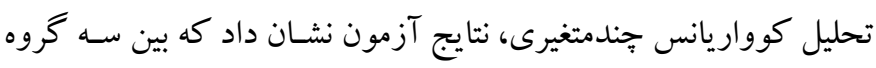

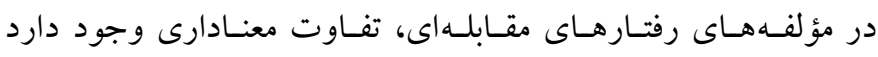
(wilks Lambda=0.11, F6.74=104.55, p<0.001) F انتـايج تحليـل كوواريـانس جنـد متغيرى در مورد مؤلفـهاى رفتارهاى مقابلهاى ارائه شده است.
براى بررسـى مقايسـه روشهاى مداخله بر مولفههاى رفتارهاى مقابلهاى

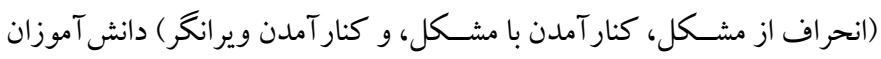

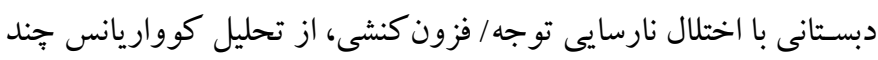

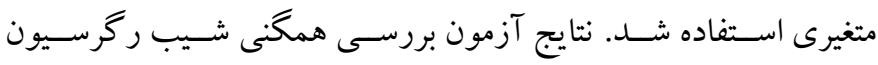

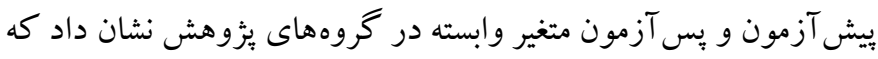

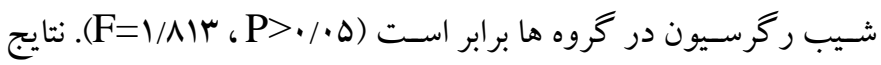
آزمون لوين براى بررسى همخنى واريانس متغير وابسته در گروهها نشان

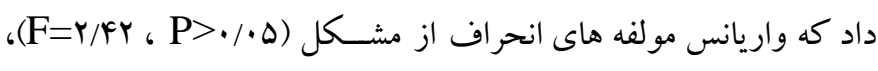

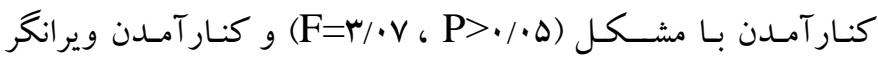
(F=l/A9 ، P>•/ه)

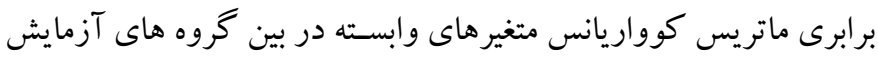


جدول ع: نتايج تحليل كواريانس جند متغيرى مؤلفههاى رفتارهاى مقابلهاى

\begin{tabular}{|c|c|c|c|c|c|c|c|c|}
\hline توان آزمون & اندازه اثر & $\mathbf{P}$ & Tماره F & ميانكين مجذورات & درجه آزادى & مجموع مجذورات & منبع تغييرات & متغير \\
\hline \multirow[t]{2}{*}{1} &.$/ 91$ &.$/ \cdot 1$ & $110 r / .9$ & ra9/A. & $r$ & $\Delta Q Y / \Delta q$ & كروه & \multirow{2}{*}{ انحر اف از مشكل } \\
\hline & & & & $\cdot / 14$ & rq & $1 . \% 4$ & خطا & \\
\hline \multirow[t]{2}{*}{1} & $\cdot / 9 r$ & $\cdot / \cdot \cdot 1$ & rIV/ar & rIV/ar & r & MaY/gV & كروه & \multirow{2}{*}{ كنار آمدن با مشكل } \\
\hline & & & & . - (Ar & rq & $M Y / F D$ & خطا & \\
\hline \multirow[t]{2}{*}{1} &.$/ 9 F$ &.$/ . \cdot 1$ & rIV/oV & rIV/DV & r & FrF/IT & كروه & \multirow{2}{*}{ كنار آمدن وير انگر } \\
\hline & & & & .191 & rq & r9/94 & خطا & \\
\hline
\end{tabular}

با مشكل، و وq درصـد كنار آمدن وير انغخر را تبيين مى كند. براى بررسى

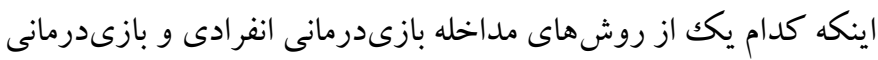

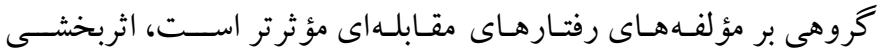

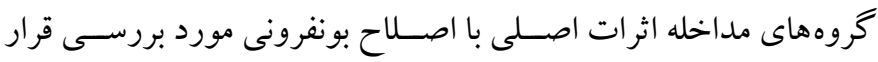

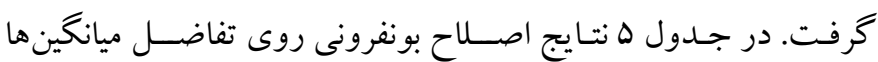

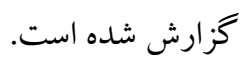

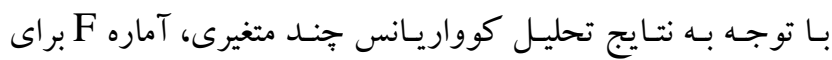

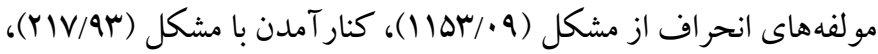

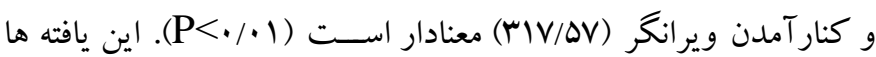
نشـانگر آن اسـت كه بين گرووها در اين مؤلفهها تفاوت معنادارى وجود

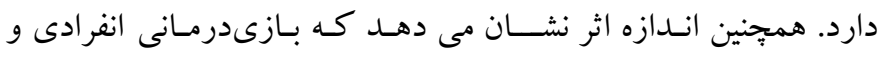

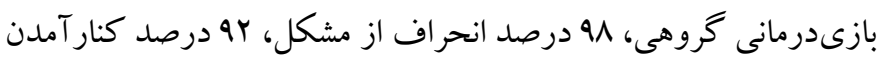

جدول 0: نتايج آزمون بونفرونى در مولفههاى رفتارهاى مقابلهاى

\begin{tabular}{|c|c|c|c|c|c|}
\hline سطح معنى دارى & خطاى استاندارد & تفاوت ميانكين هاى تعديل شده & كروه مورد مقايسه & كروه مبنا & متغير \\
\hline.$/ .1$ &.$/ 19$ & $F / F Y$ & بازىدرمانى انفرادى & كروه گواه & \\
\hline$\cdot \cdots 1$ & $\cdot / 19$ & $9 / \cdot \vee \vee$ & بازىدرمانى گروهى & كروه گواه & انحر اف از مشكل \\
\hline$\cdot / \cdot 1$ & $\cdot / 19$ & F/90 & بازىدرمانى گروهى & بازىدرمانى انفرادى & \\
\hline.$\cdots 1$ & $\cdot / \mu 4$ & $-r / F V$ & بازىدرمانى انفر ادى & كروه گواه & \\
\hline$\cdot \cdots 1$ & $\cdot / \mu F$ & $-V / \cdot 9$ & بازىدرمانى گروهى & كروه گواه & كنار آمدن با مشكل \\
\hline$\% \cdot 1$ & $\cdot / 4 \Delta$ & $-r / 91$ & بازىدرمانى گروهى & بازىدرمانى انفرادى & \\
\hline$\cdot / \cdot 1$ & $\cdot / \mu 1$ & $r / \cdot \wedge$ & بازىدرمانى انفرادى & كروه گواه & \\
\hline 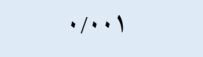 & $\cdot / \mu 1$ & $V / V F$ & بازىدرمانى گروهى & كروه گواه & كنار آمدن ويرانگر \\
\hline.$/ .1$ & D & $r / 94$ & بازىدرمانى گروهى & بازىدرمانى انفرادى & \\
\hline
\end{tabular}

\section{بحث و نتيجه كيرى}

هدف از انجام يزٔوهش حاضـر، مقايسه اثربخشسى بازى بدرمانى انفر ادى و

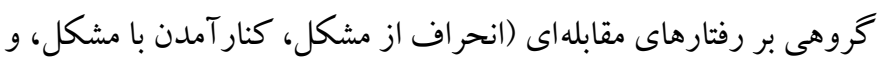

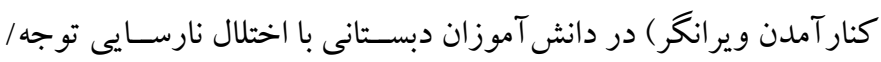

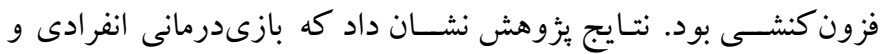

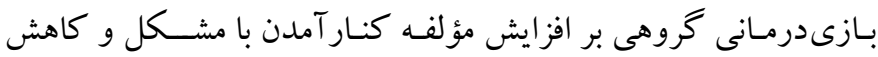
مؤلفههاى انحراف از مشـكل، و كنار آمدن وير انكخر تأثير معنادار داشـتند.

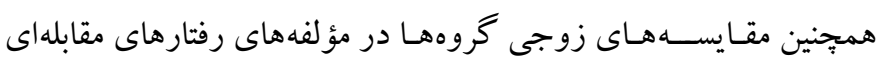

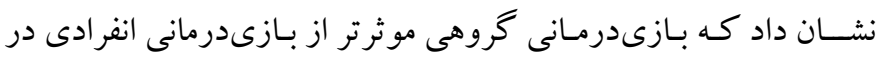

همان طور كه در جدول ها مشاهده مىشود، در مولفههاى انحراف از

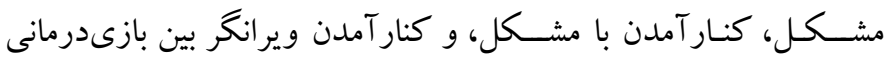

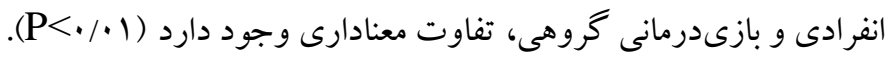

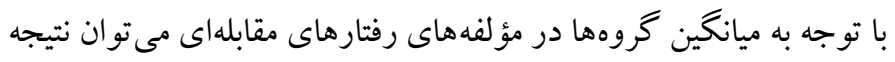

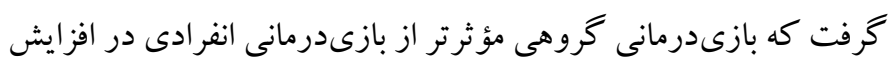

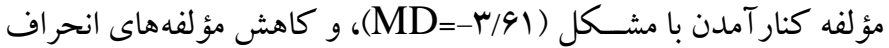

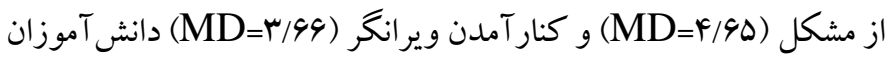

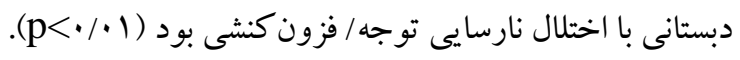


امكان طرد شـدن از سوى همسالان به جهت برخاشخرى، رعايت نكردن

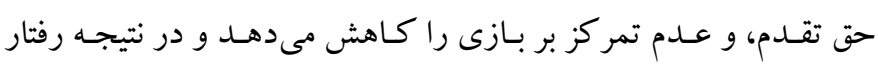

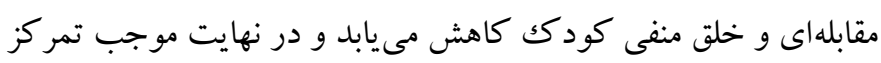

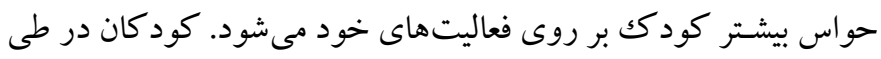

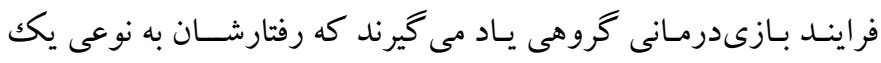

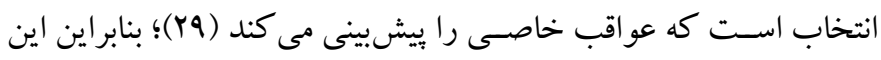

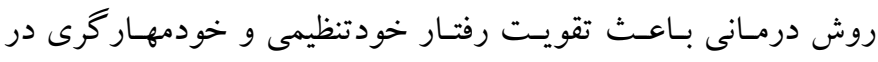

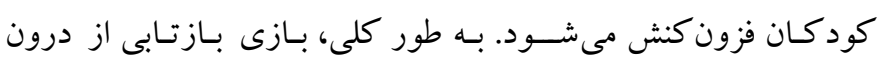

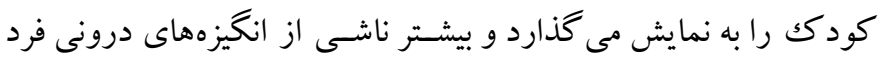

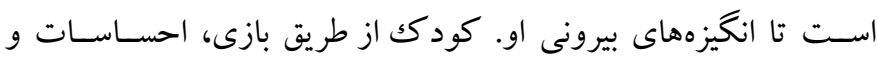

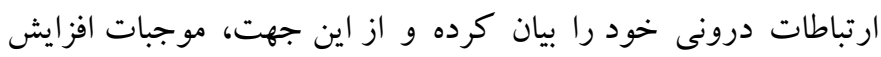

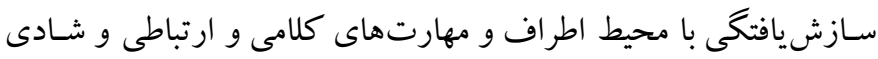

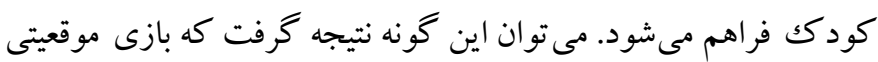

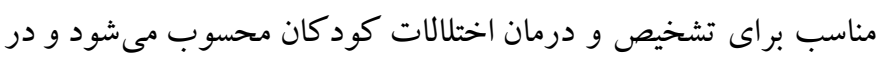
نتيجه براى كود كان بسيار مفيد است (YV)

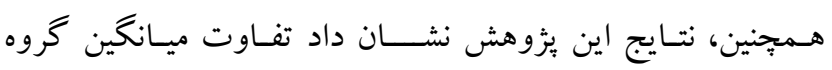

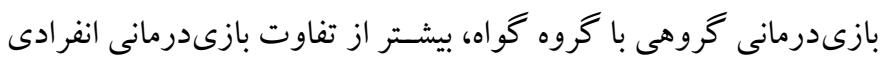

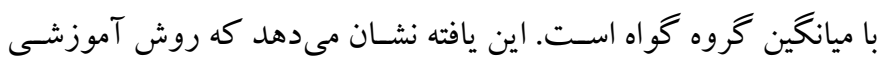

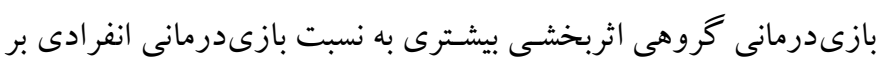

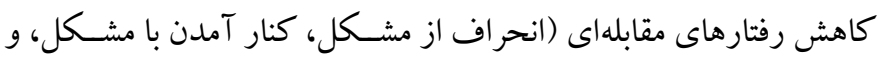

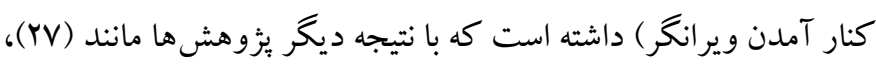

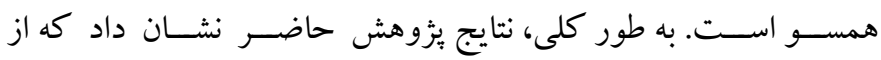

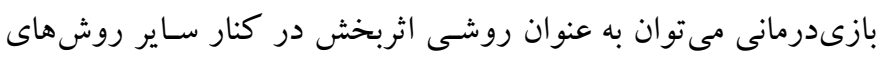

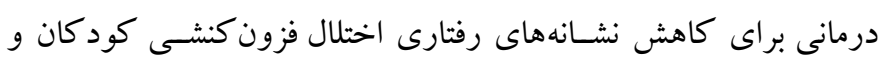
بهبود رفتارهاى مقابلهاى آنها بهره جسـت. اين نتيجه در راستاى نظريه

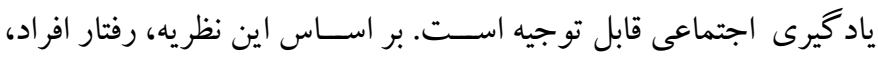

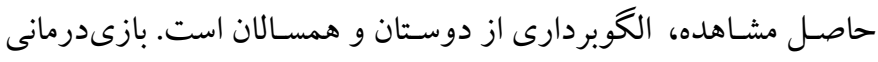

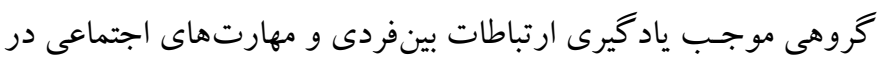

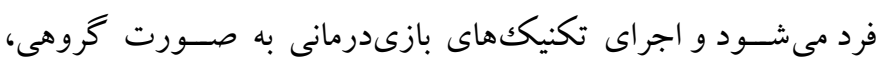
نقش عمدهاى در افزايش اين مهارتها داشسته اسـت. همجينين اجراى

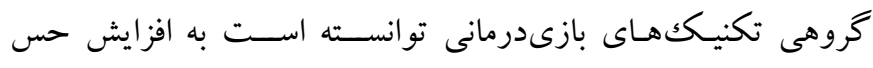

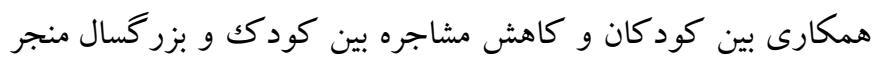

افزايش مؤلفه كنار آمدن با مشكل، و كاهش مؤلفههاى انحر اف از مشكل

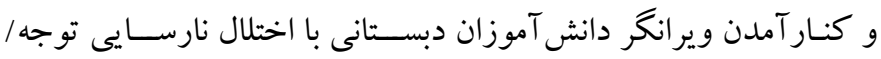

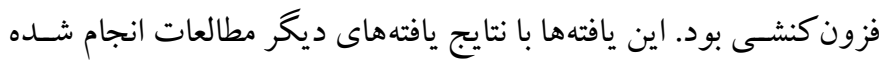

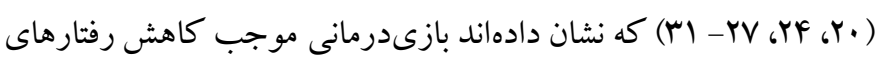

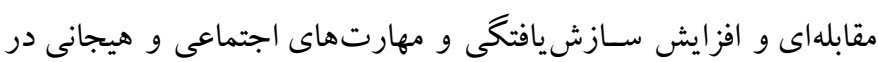
كود كان مىشود، همسو است. در تفسير نتايج اين مطالعه مى توان بيان كرد كه در مطالعه حاضر در مرد

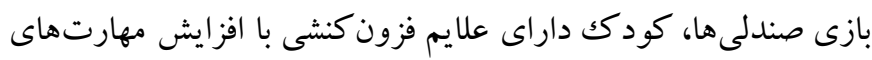

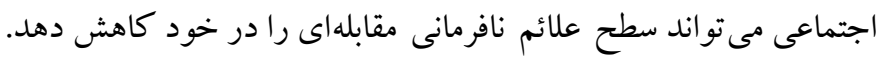

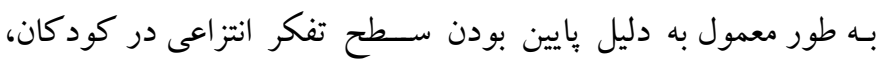

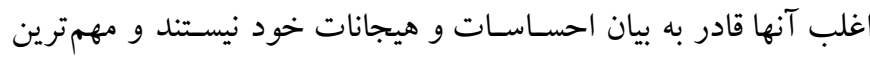
تكنيكى كه به كود كان اين اجازه ارائه مسـائلى رامىدهد كه قادر به

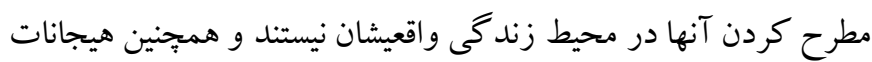

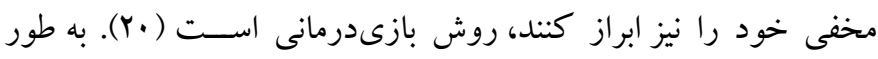

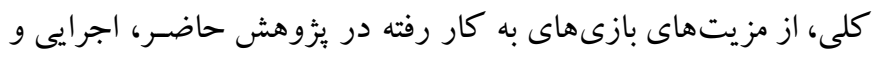

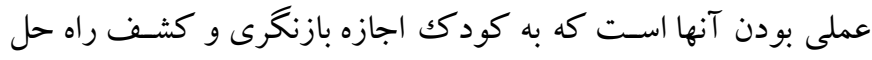
مناسـب مسـائل را، به جاى صسحبت كردن مىدهند. تحول هيجانى و

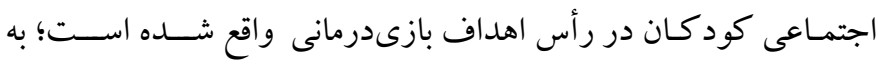

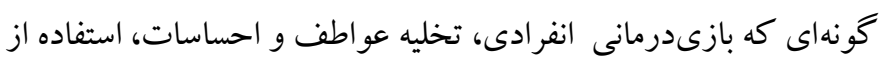

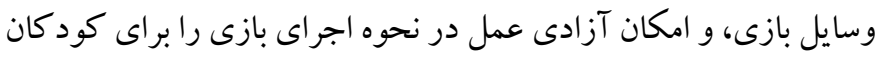

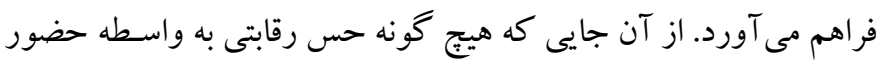

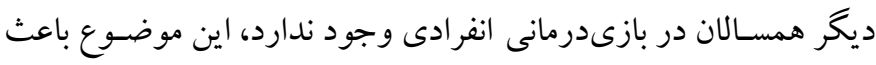

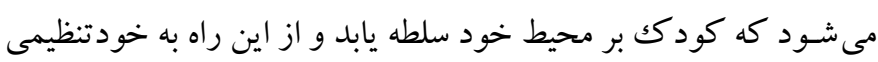

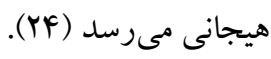

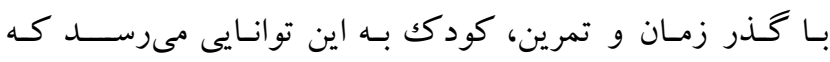

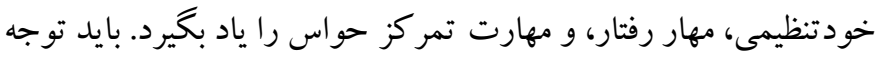

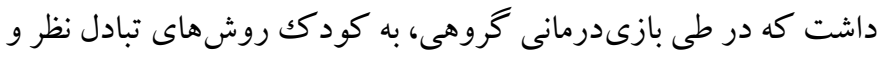

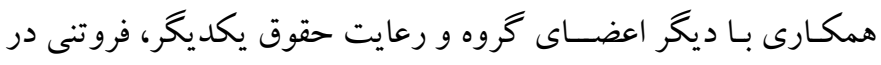

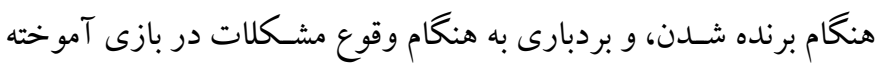

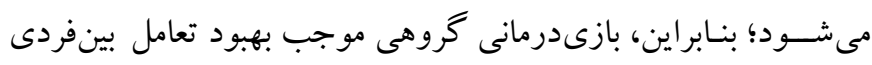

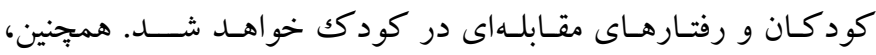

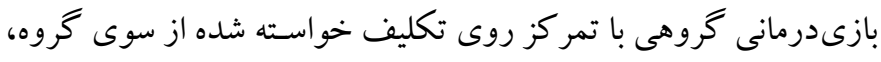


كود كان فزون كنش عنوان شـد، بايد يذيرفت كه از نظر متخصص بالينى تفاوت اثربخشـى دو بازىدرمانى انفرادى و كروهى، ناهيز اســــ اين

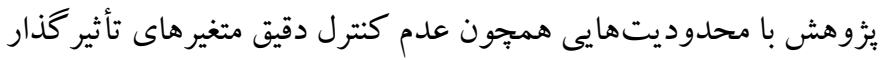

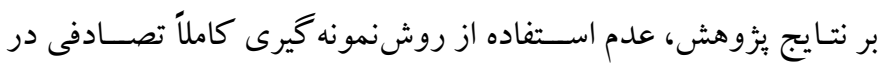
تمامى مراحل انتخاب نمونه، و عدم كنترل وضسعيت تحصسيلى والدين را

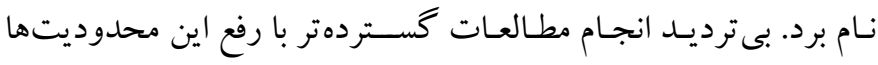

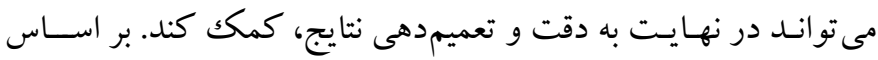

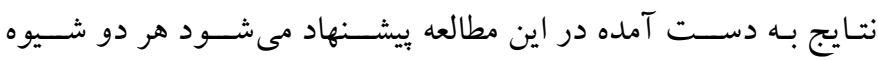

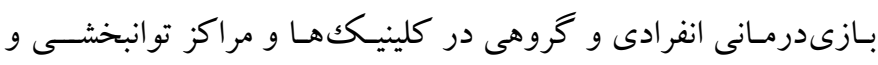
درمانى براى بهبود وضسعيت رفتارى و روانشــناختى كود كان با اختلال نارسايى توجه / فزون كنشى استفاده شود.

تشكر و قدردانى: اين مقاله بر گرفته از رسـاله دكتراى خانم الهه نايبى با كد . 1.9Y.V.99VYIII. راهنما و مشــاور اين رسـاله، مربيان و كادر ادارى مدارس منتخب، و همجنين افراد نمونه و والدين آنها، تشكر و قدردانى مى مشود. تضــاد منافع: اين يُزوهش براى نويسـند كان هيج كونه تضــاد منافعى نداشـــه

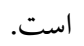

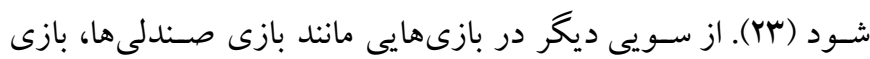

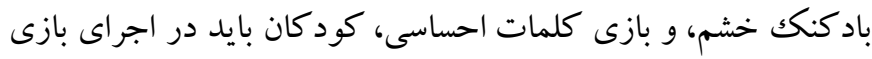

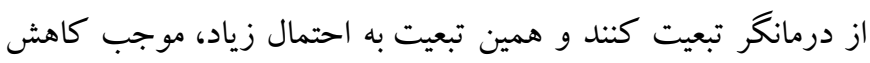

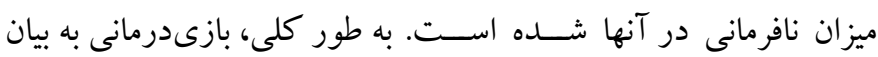

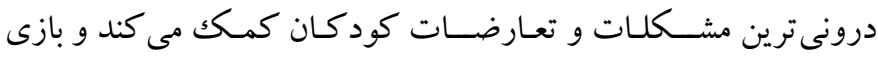
مهم ترين تكنيكى است كه به كود كان اجازه مىدهد احساسات خودشان را به صورت طبيعى نشان دهند (YY)؛ به گگونهاى كه كود كان با بازنمايى

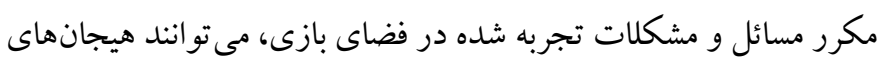

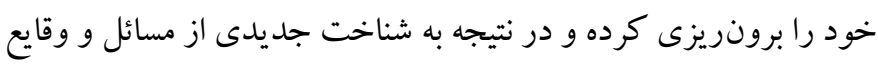
اطر اف خود برسند. در بايان مى توان به اين نكته اشـاره كرد كه گاهى اوقات، تفاوت دو برد كروه مورد بررسى، از نظر بالينى معنادار نيست، اما از نظر آمارى معنادار

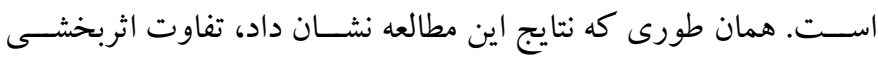

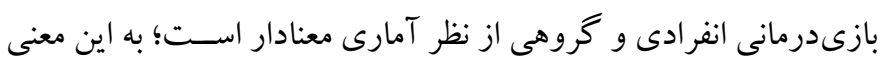

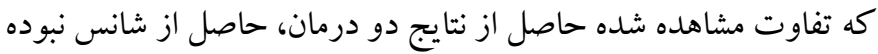
اسـت؛ به عبارتى، تفاوت مشـاهده شــده از نظر متخصـص بالينى، تفاوت

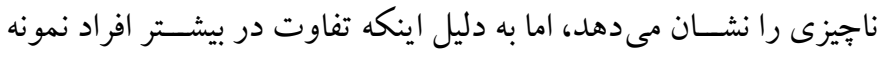

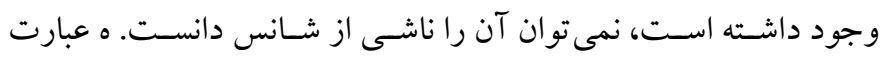

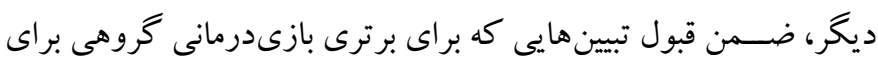




\section{References}

1. Gosch EA. Treating a Child with Anxiety and Attention-Deficit/Hyperactivity Disorder? Don't Rule Out Cognitive-Behavioral Therapy. 2018. [Link]

2. Groenman AP, Schweren LJ, Weeda W, Luman M, Noordermeer SD, Heslenfeld DJ, Franke B, Faraone SV, Rommelse N, Hartman CA, Hoekstra PJ. Stimulant treatment profiles predicting co-occurring substance use disorders in individuals with attentiondeficit/hyperactivity disorder. European child \& adolescent psychiatry. 2019 Feb 5:1-0. [Link]

3. Mohr-Jensen C, Steen-Jensen T, Bang-Schnack M, Thingvad $\mathrm{H}$. What do primary and secondary school teachers know about ADHD in children? Findings from a systematic review and a representative, nationwide sample of Danish teachers. Journal of attention disorders. 2019 Feb; 23(3):206-19. [Link]

4. MacLeod C. Current Range of Treatments and Therapies in Children and Adolescents Diagnosed With ADHD; A Systematic Review of the Literature. 2018. [Link]

5. Alizadeh H, Armion E, Coolidge FL, Flores ZD, Sutton CE. The prevalence of attentiondeficit/hyperactivity disorder among primary school students in an Iranian rural region. Psychology. 2015 Feb 12; 6(03):263. [Link]

6. Eiraldi R, Mautone JA, Khanna MS, Power TJ, Orapallo A, Cacia J, Schwartz BS, McCurdy B, Keiffer J, Paidipati C, Kanine R. Group CBT for externalizing disorders in urban schools: Effect of training strategy on treatment fidelity and child outcomes. Behavior therapy. 2018 Jul 1; 49(4):53850. [Link]

7. Niec LN, Barnett ML, Prewett MS, Shanley Chatham JR. Group parent-child interaction therapy: A randomized control trial for the treatment of conduct problems in young children. Journal of consulting and clinical psychology. 2016 Aug; 84(8):682. [Link]

8. Booker JA, Capriola-Hall NN, Dunsmore JC, Greene RW, Ollendick TH. Change in maternal stress for families in treatment for their children with oppositional defiant disorder. Journal of child and family studies. $2018 \mathrm{Jul}$ 1; 27(8):2552-61. [Link]

9. Golubchik P, Shalev L, Tsamir D, Manor I, Weizman A. High pretreatment cognitive impulsivity predicts response of oppositional symptoms to methylphenidate in patients with attention-deficit hyperactivity disorder/oppositional defiant disorder. International clinical psychopharmacology. 2019 May 1; 34(3):138-42. [Link]
10. Juárez-Treviño M, Esquivel AC, Isida LM, Delgado DÁ, de la O Cavazos ME, Ocañas LG, Sepúlveda RS. Clozapine in the treatment of aggression in conduct disorder in children and adolescents: a randomized, double-blind, controlled trial. Clinical psychopharmacology and neuroscience. 2019Feb; 17(1): 43. [Link]

11. Sadek J. ADHD and Oppositional Defiant Disorder (ODD). InClinician's Guide to ADHD Comorbidities in Children and Adolescents 2019 (pp. 37-45). Springer, Cham. [Link]

12. Laezer KL. Effectiveness of psychoanalytic psychotherapy and behavioral therapy treatment in children with attention deficit hyperactivity disorder and oppositional defiant disorder. Journal of Infant, Child, and Adolescent Psychotherapy. 2015 Apr 3; 14(2):111-28. [Link]

13. Swank JM, Smith-Adcock S. On-task behavior of children with attention-deficit/hyperactivity disorder: Examining treatment effectiveness of play therapy interventions. International Journal of Play Therapy. 2018 Oct; 27(4):187. [Link]

14. Bagherizadeh H, Nasab HM, Goudarzvand R. The effect of play therapy on symptoms of oppositional defiant disorder in boys aged 5 to 10 years old. Int $\mathbf{J}$ Learn Develop. 2015; 5(2):48-55. [Link]

15. Ho RT, Lai AH, Lo PH, Nan JK, Pon AK. A StrengthBased Arts and Play Support Program for Young Survivors in Post-Quake China: Effects on SelfEfficacy, Peer Support, and Anxiety. The Journal of Early Adolescence. 2017 Jun; 37(6):805-24. [Link]

16. Palmer CG, Boudreault P, Berman BA, Wolfson A, Duarte L, Venne VL, Sinsheimer JS. Bilingual approach to online cancer genetics education for Deaf American Sign Language users produces greater knowledge and confidence than English text only: A randomized study. Disability and health journal. 2017 Jan 1; 10(1):23-32. [Link]

17. Seymour JW. Resilience-enhancing factors in play therapy. Play Therapy Interventions to Enhance Resilience. 2015 May 4. [Link]

18. Ariel S. Integrative Play Therapy with Individuals, Families and Groups. Routledge; 2019 May 13. [Link]

19. Pittala ET, Saint-Georges-Chaumet Y, Favrot C, Tanet A, Cohen D, Saint-Georges C. Clinical outcomes of interactive, intensive and individual (3i) play therapy for children with ASD: a two-year follow-up study. BMC pediatrics. 2018 Dec; 18(1):165. [Link]

20. Meany-Walen KK, Teeling S. Adlerian play therapy with students with externalizing behaviors and poor 
social skills. International Journal of Play Therapy. 2016 Apr; 25(2):64. [Link]

21. Mahmood alilo M, Hashemi Nosratabad T, Farshbaf Manisefat F. The effectiveness of play therapy according levy approach in reduction of anxiety in children with diagnosed cancer. J Holist Nurs Midwifery. 2015; 25 (1):54-62. [Link]

22. Meany-Walen KK, Kottman T. Group Adlerian play therapy. International Journal of Play Therapy. 2019 Jan; 28(1):1. [Link]

23. Kwon YJ, Lee K. Group child-centered play therapy for school-aged North Korean refugee children. International Journal of Play Therapy. 2018 Oct; 27(4):256. [Link]

24. Phipps CB. The Effect of Child-Centered Play Therapy on the Externalizing Behaviors of Low Income Male Preschoolers during Group Instructional Time and Center Time: A Single-Case Design Study. ProQuest LLC. 2017. [Link]

25. Cheng YJ, Ray DC. Child-centered group play therapy: Impact on social-emotional assets of kindergarten children. The Journal for Specialists in Group Work. 2016 Jul 2; 41(3):209-37. [Link]

26. Ojiambo D, Bratton SC. Effects of group activity play therapy on problem behaviors of preadolescent Ugandan orphans. Journal of Counseling \& Development. 2014 Jul; 92(3):355-65. [Link]

27. Morshed N, Babamiri M, Zemestani M, Alipour N. A Comparative Study on the Effectiveness of Individual and Group Play Therapy on Symptoms of Oppositional Defiant Disorder among Children. Journal of the Korean Academy of Family Medicine. 2019 Jan 9. [Link]

28. Alavi S, Razavi V, Tehrani M. Group Play Therapy on Behavioral Disorders in Preschool Children. 2018, 7-3/26-31. [Link]

29. Morshed N, Davoodi I, Babamiri M. Effectiveness of group play therapy on symptoms of oppositional defiant among children. J Educ Community Health. 2015 Dec 15; 2(3):12-8. [Link]

30. Nikpour G, Zare poor M, Nikpour F. The Effect of Play Therapy with Cognitive Behavioral Approach on Reducing Oppositional Defiant Disorder Symptoms in
Children Aged 8 to 11 Years. TB. 2018; 17 (1):62-72. [Link]

31. Ariapooran S, Eskandari A. Effectiveness of Group Play Therapy on Symptoms of Oppositional Defiant and Behavior Disorder in 6-9 Age Children with Attention Deficit/Hyperactivity Disorder. JPEN. 2016; 2 (4):44-50. [Link]

32. Ashori M, Dallalzadeh Bidgoli F. The Effectiveness of Play Therapy Based on Cognitive-Behavioral Model: Behavioral Problems and Social Skills of PreSchool Children with Attention Deficit Hyperactivity Disorder. Jrehab. 2018; 19 (2) :102-115 [Link]

33. Asgari Nekah S M, Abedi Z. The Effectivness of Executive Functions based Play Therapy on improving Response Inhibition, planning and working memory in children with Attention Deficit Hyperactivity Disorder. JCP. 2014; 2 (1) :41-51 [Link]

34. Fallahi M, Kafie Masuleh M, Khousro Javid M, Karimi Lie Chahei R, Eskandari B. [A Preliminary Evaluation of the Psychometric Properties of the Children's Coping Behavior Questionnaire (CCBQ) (Persian)]. Iranian Journal of Psychiatry and Clinical Psychology. 2018; 23(4):494-509. [Link]

35. Conners, C. K., Erhardt, D., Epstein, J. N., Parker, J. D. A., Sitarenios, G., Sparrow, E. Self-ratings of ADHD symptoms in adults I: Factor structure and normative data. J Atten Disord, 1999 3, 141-151. [Link]

36. Arabgol F, Hayati M, Hadid M. Prevalence of hyperactivity disorder / attention deficit group of students. J new cogn sci. 6(1), (2003), pp 34-51. [Persian]. [Link]

37. Soleimany AS, Sadeghi HA, Zerehpoush A, Rabie M, Abedi A, Esmaeeli S. Effectiveness of rhythmic games on social skills of children with attention deficit hyperactive disorder. Journal of Gorgan University of Medical Sciences. 2016; 18(2): 91-96. [Link]

38. Yazdanipur N, Yazdkhasti F. The effectiveness of group play on social skills of preschool children in Isfahan, Iran. Journal of research in behavioural sciences 2012, 10(3): 221 - 228. [Link] 